\title{
The Threat to Ethiopian Development: A Narrative Analysis of the Crisis in Ethiopia
}

\author{
Babatunde A. Akinbobola \\ Department of Public Administration \& Policy, Nelson Mandela College of Government and Social Sciences \\ Southern University and A \& M College
}

\begin{abstract}
The purpose of this research is to highlight the dangers and threats that conflict or crisis brings to nations, regions, towns, and citizens as whole to inform public policy. The study utilizes the ongoing crisis in Ethiopia as a casestudy for the purpose of discussion. The study follows a narrative literature review approach to analyze the study. The study used a Boolean search approach to obtain the relevant literature to support the study analysis. As part of the study findings, the literature reveals that more than 5.2 million people in Tigray, Ethiopia, are in dire need of humanitarian support, including health care, due to the conflict that erupted at the end of 2020. The conflict has left thousands of residents of Tigray region with injuries, emotional and psychological trauma and had a severe impact on the families' lives and livelihoods. It was also observed from the literature that over 2.1 million people have been displaced and are living in crowded settings with limited access to water and sanitation infrastructure. The study further reveals in the literature that the crisis or conflict has a spatial-spillover on the neighboring regions, towns, and residents in Ethiopia. A particular example was observed from the spillover of the conflict into the neighboring regions of Afar and Amhara in the northern part of the country, Ethiopia. The study recommended that policymakers, international peace-advocates, Africa Union should act fast to assist Ethiopia to end the ongoing crisis in order to restore peace and bring back development to Ethiopia and the surrounding countries.

Keywords: Conflict, Development, Spillover, Crisis, Threat, Violence, Development, healthcare, Economies, and post-Conflict Resolutions

DOI: $10.7176 / \mathrm{JESD} / 12-24-04$

Publication date: December $31^{\text {st }} 2021$

\section{INTRODUCTION}

Over the past decade, a new awareness of the relationship between conflicts and development has grown (Ginty \& Williams, 2009). Developmental factors can act as a trigger for violence, as well as for ending violence and for triggering post-conflict reconstruction (Ginty \& Williams, 2009). This article explores the complexity of the links between violent conflict (usually civil wars) and development, under-development and uneven development. It emphasizes the connections between stable developed economies and civil wars in other parts of the world, and examines how structural factors (such as the organization of the global economy) virtually condemn some regions to conflict and under-development. Particularly, the focus will be geared toward Ethiopian economy, where there seems to a threat to their respective development due to the ongoing crisis in Tigray region.

As a result of the ongoing crisis in Tigray region of Ethiopia, the region has features on the International Rescue Committee's annual Emergency Watchlist for the third year in a row but rises into the top five for the first time due to escalating conflict (Ayene, 2021; Wealth Health Organization, 2021). Here's what you need to know about the humanitarian emergency in Ethiopia. As part of the threat of crisis to development, it is observed from the literature that more than 5.2 million people in Tigray, Ethiopia, are in dire need of humanitarian support, including health care, due to the conflict that erupted at the end of 2020 (Ayene, 2021; Wealth Health Organization, 2021). The conflict has left thousands of residents of Tigray region with injuries, emotional and psychological trauma and had a severe impact on the families' lives and livelihoods. The spillover of the conflict into the neighboring regions of Afar and Amhara is significantly increasing humanitarian needs in the northern part of the country (See Figure 1 for more details).
\end{abstract}


Figure 1: A Map Showing the Spillover of the Conflict into the Neighboring Regions of Afar and Amhara in Ethiopia

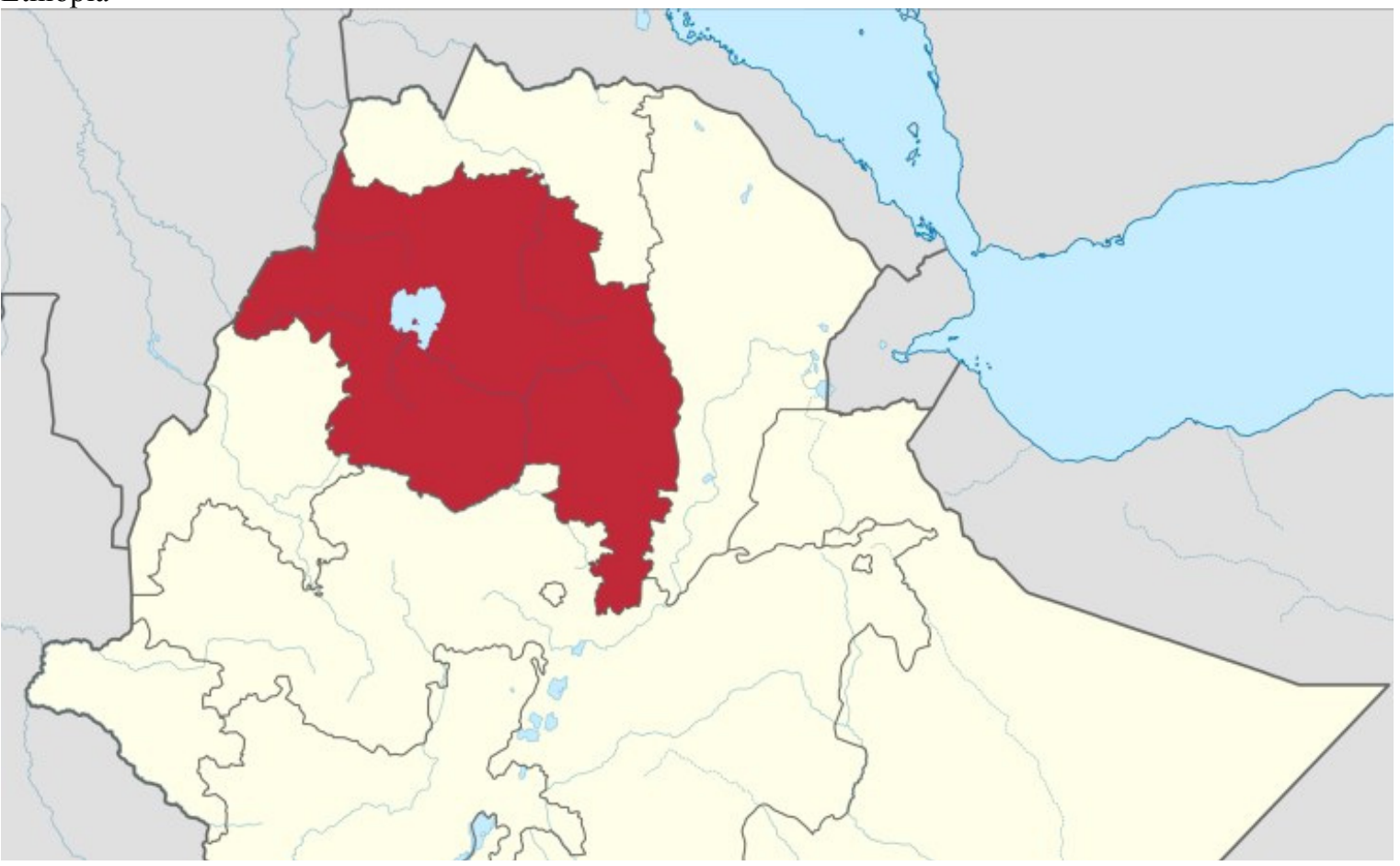

Source: TUBS / NordNordWest / Wikimedia Commons, 2021

Statistically, according to the literature, over 2.1 million people have been displaced and are living in crowded settings with limited access to water and sanitation infrastructure. Over half of the health facilities in Tigray are not operational (Ayene, 2021; Wealth Health Organization, 2021). People are suffering from trauma and injuries, food insecurity and malnutrition, sexual and gender-based violence, communicable diseases such as malaria, cholera, as well as reduced access to treatment for non-communicable diseases and maternal and child health services (Ayene, 2021; Wealth Health Organization, 2021). The conflict has also disrupted the COVID-19 response. Millions of people are facing acute food insecurity in the region, with over 400000 people close to famine. Access to affected areas remains limited, making the scale-up of the health response difficult even as the population's needs are growing, especially for children, women, and internally displaced people (Wealth Health Organization, 2021).

As Global Health Cluster lead, WHO is coordinating with 23 partners in Tigray and neighboring areas to provide the affected populations with emergency health support, including on prevention, preparedness and response to disease outbreaks (Wealth Health Organization, 2021). In 2020, conflict broke out in the northern Tigray region of Ethiopia between the federal government and the Tigray People's Liberation Front (TPLF), sparking ongoing violence and instability (Wealth Health Organization, 2021). At the same time, Ethiopia has been suffering from the largest locust outbreak in recent history, the deadly effects of climate change, and the COVID-19 pandemic.

As 2021 unfolds, vulnerable communities in Ethiopia who've already been stretched too thin will struggle to access necessary food and resources, driving up the number of people in need to the second highest in the world (Wealth Health Organization, 2021). "With over 21 million people already in need of humanitarian assistance and this number now rising due to the crisis in Tigray, we must ensure that nothing disrupts humanitarian access and programming," says Richard Data, the IRC's interim deputy director of emergencies for Ethiopia (Wealth Health Organization, 2021).

\section{Why This Study?}

The focus of the study setting is geared towards Ethiopia due to the ongoing crisis, and the postulation made by Ayene (2021). According to Ayene (2021) there are several reasons Ethiopia is one of the countries' most at risk of humanitarian catastrophe in 2021, for the third year in a row. Some of the intriguing factors that called for attention to the ongoing crisis in Ethiopia include the following:

First, the conflict in the Tigray region sparks refugee movements amid allegations of violence against civilians. When 2020 began, political tensions had already been growing in the Tigray region of Ethiopia. Conflict escalated rapidly in November when Prime Minister Abiy Ahmed accused the TPLF of attacking a military base. Civilians and vulnerable communities are now being affected by the violence, with many fleeing to neighboring Sudan. Amnesty International has documented allegations of at least one massacre of civilians as a result of the fighting. 
The United Nations has also estimated that 9 million people are living in areas that could be affected by conflict. The IRC and other organizations working in Tigray are planning for as many as 2 million people to be displaced internally and for around 400,000 to flee to Sudan in search of safety (Ayene, 2021; Wealth Health Organization, 2021).

Second, the ongoing political tensions increase the risk of instability across the country. Tigray doesn't exist in a vacuum. The political tensions growing there are also present in other parts of Ethiopia. As conflict and fighting endure in Tigray, instability may spread across the country and aggravate the situation in neighboring countries too, causing millions more people to face violence and flee their homes safety (Ayene, 2021; Wealth Health Organization, 2021). Specifically, upcoming elections in 2021 may cause political tensions to remain elevated. If federal security forces continue to keep their focus on Tigray, armed groups in other parts of Ethiopia may see an opportunity to step up their activity's safety (Ayene, 2021; Wealth Health Organization, 2021). Towards this end, the Ethiopian crisis facts is very alarming. In relation to the available facts and data with respect to the ongoing crisis, it is observed from the literature that about 21.3 million people need humanitarian aid; 1.8 million people are internally displaced; 792,000 refugees are seeking safety, mostly from South Sudan, Somalia and Eritrea; and above all, the region is Ranked 84th of 195 countries for capability to prevent and mitigate epidemics (Ayene, 2021; Wealth Health Organization, 2021).

Figure 2: A Map of Ethiopia Showing the Crisis Zone- Tigray

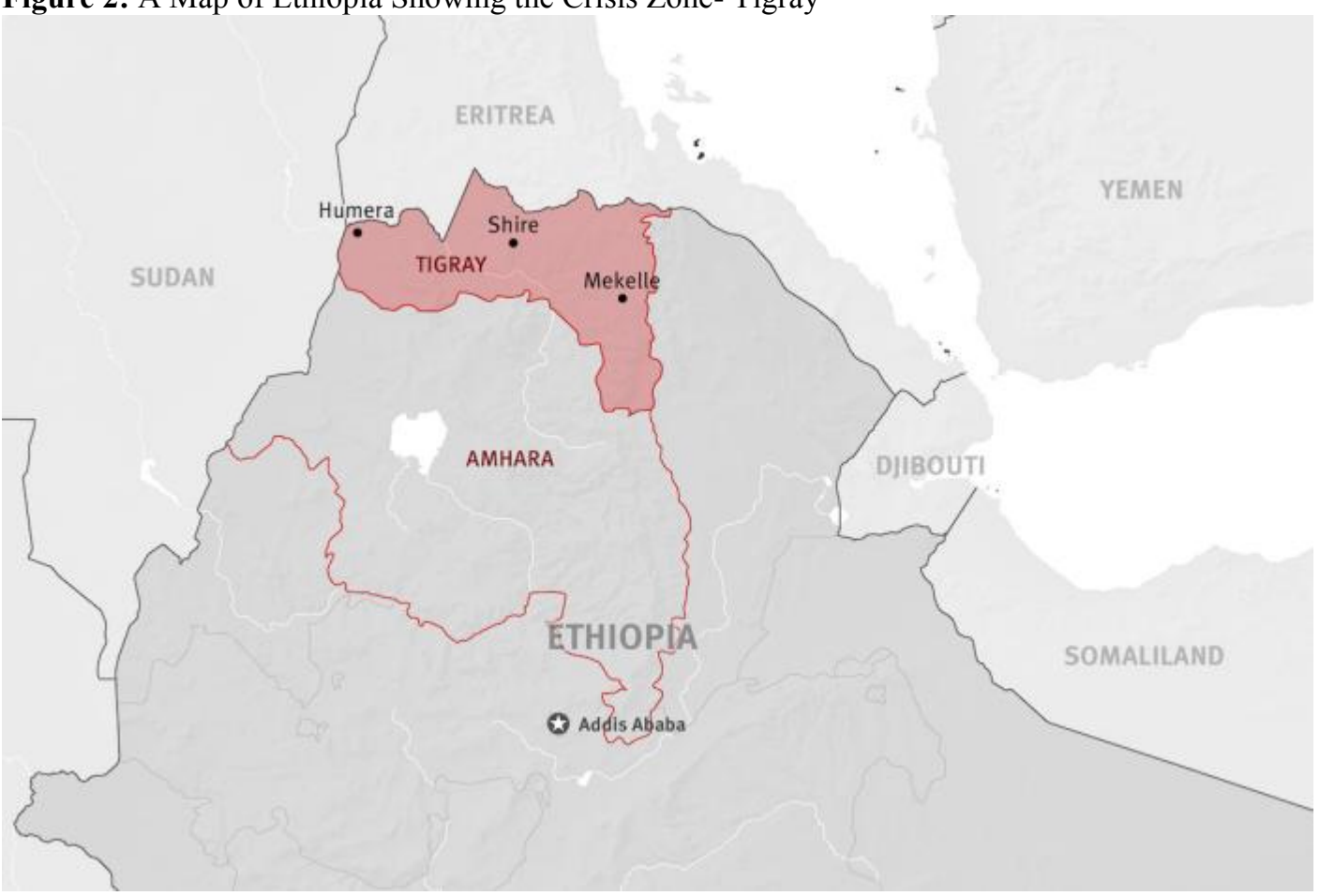

\section{Source: Human Rights Watch}

As a result of the above statistics, it is therefore very necessary for policymakers, and international peaceadvocates to get to know more about the critical needs of their intervention to help salvage the development crisis that war-tone regions, district, and nations, particularly for Ethiopia. Therefore, this study is conducted to highlight the dangers and threats that conflict or crisis brings to nations, regions, towns, and citizens as whole to inform public policy, by focusing on the ongoing crisis in Ethiopia.

\section{LITERATURE REVIEW}

In this review, the study examines the association between development and conflict or civil unrest. By development, the researcher refers broadly to ability to live peacefully, access to basic amenities, food, shelter, and reduction in conflict related crimes. Conflict either occur within-country, and between countries. Meanwhile, according to the literature, within-country unrest, ranging from peaceful demonstrations, processions, and strikes to violent riots and civil war (Ray \& Esteban, 2017).

Within-country conflicts account for an enormous share of the deaths and hardships in the world today (Ray \& Esteban, 2017). Since World War II, there have been 22 interstate conflicts with more than 25 battle-related deaths per year; 9 of these conflicts have killed at least 1,000 people over the entire history of the conflict (Gleditsch et al., 2002). The total number of attendant battle deaths in these conflicts is estimated to be around 3 to 8 million (Bethany \& Gleditsch, 2005). The very same period has witnessed 240 civil conflicts with more than 25 battle-related deaths per year, and almost half of these conflicts killed more than 1,000 people (Gleditsch et al., 
2002). Estimates of the total number of battle deaths in these conflicts are in the range of 5 to 10 million (Bethany \& Gleditsch, 2005).

In 2015, there were 29 ongoing conflicts that had killed 100 or more people in 2014, with cumulative deaths for many of them climbing into the tens of thousands. Figure 1 depicts global trends in inter- and intrastate conflict and Figure 2 the distribution of these conflicts over the world regions (Ray \& Esteban, 2017).

Figure 1: Armed conflicts by type, 1946-2015. Conflicts include cases with at least 25 battle deaths in a single year.

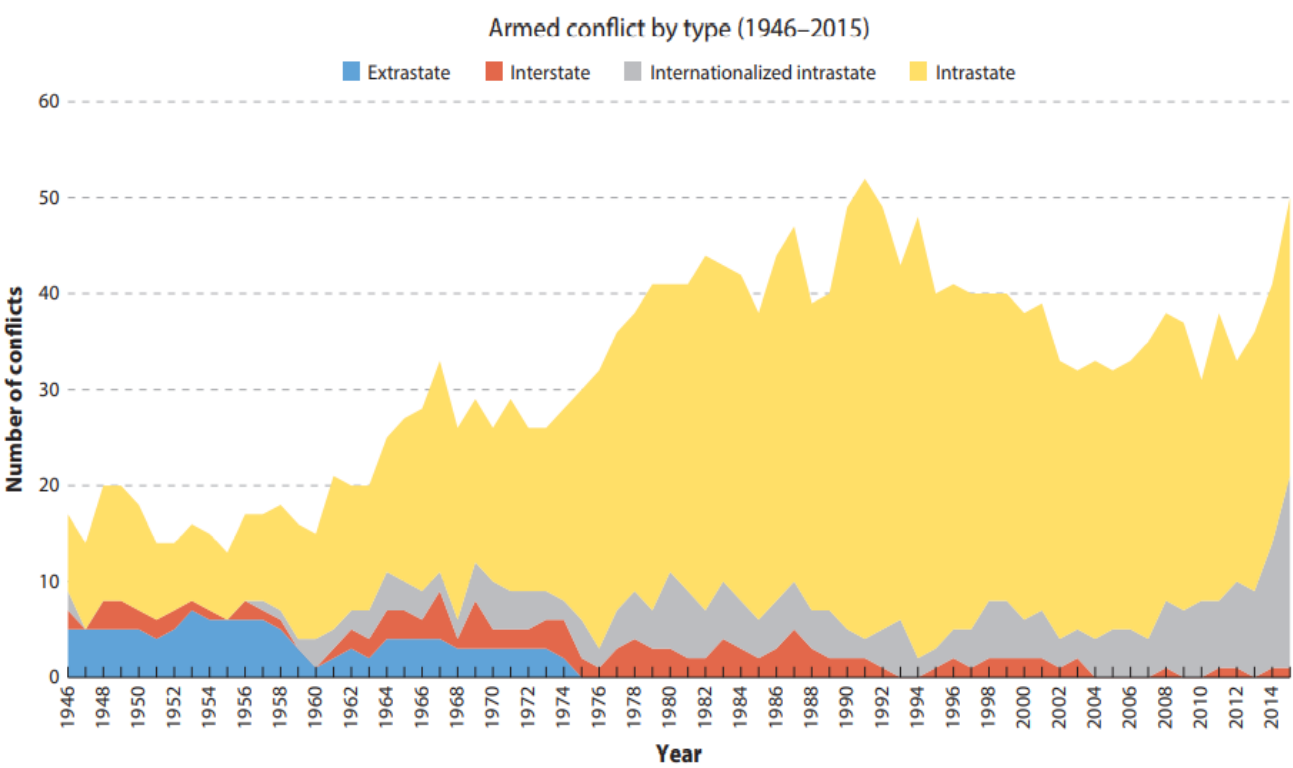

Source: Retrieved from Melander et al. (2016) cited in Ray \& Esteban (2017).

Figure 2: Armed conflicts by Region, 1946-2015. Conflicts include cases with at least 25 battle deaths in a single year.

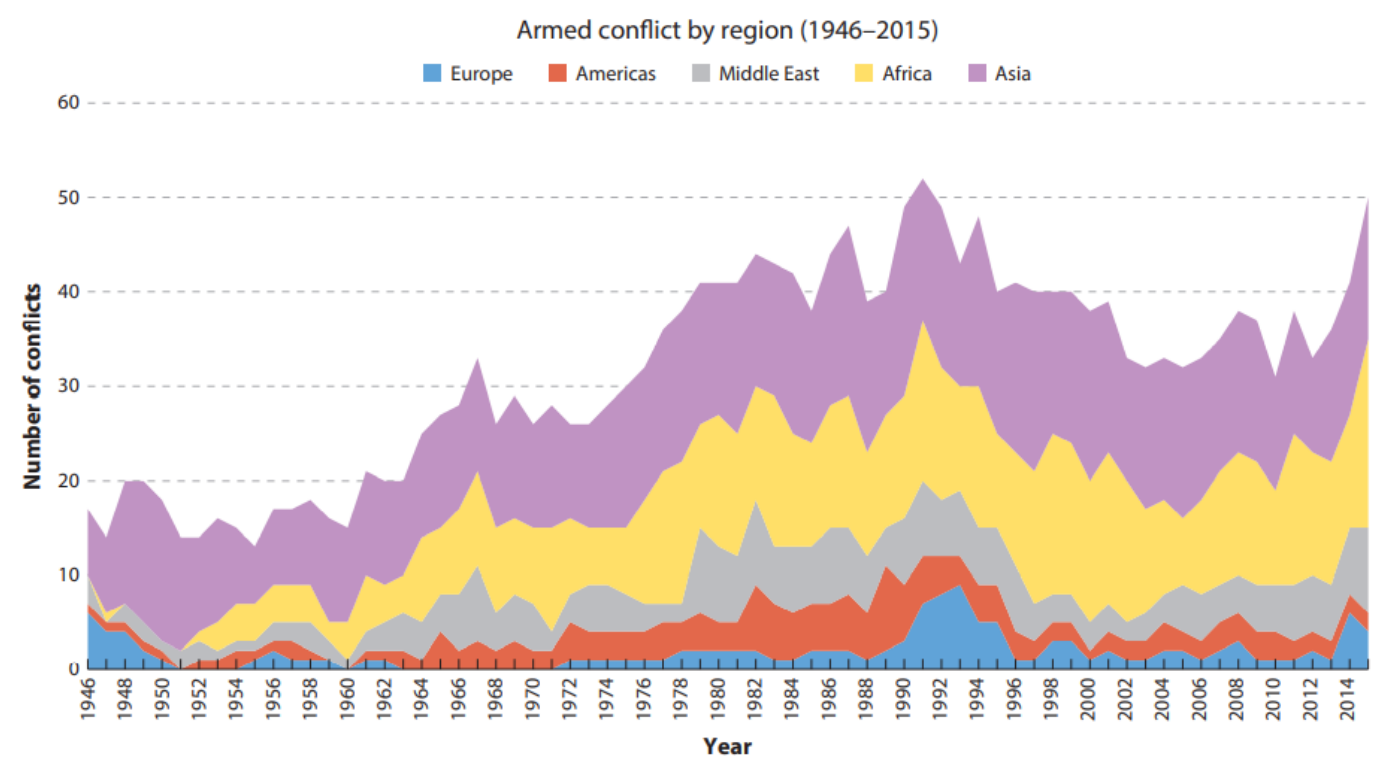

Source: Retrieved from Melander et al. (2016) cited in Ray \& Esteban (2017).

\section{Economic Development and Conflict}

Systematic empirical studies of conflict begin with the work of Collier \& Hoeffler $(1998,2004)$ and Fearon \& Laitin (2003). These are cross-sectional studies (presumably) aimed at establishing the correlates of civil war, though causal interpretations have all too readily been advanced. Perhaps the most important finding from this literature is that conflict is negatively related to per capita income. In this section, we discuss alternative interpretations of this finding, but we also critically examine the finding itself. 
Collier \& Hoeffler (1998, 2004a) and Fearon \& Laitin (2003) observe that per capita income and conflict are significantly and negatively correlated. Table 1 reproduces the central table used by Fearon \& Laitin (2003). They study the onset of "civil war," which they define as (a) "fighting between agents of (or claimants to) a state and organized, nonstate groups," having (b) a yearly average of at least 100 deaths, with a cumulative total of at least 1,000 deaths and (c) at least.

Dal Bo \& Dal B ' o (2011) formalize this idea in the context of a simple general equilibrium model. They consider an economy with several sectors: The productive sectors differ (as in the Heckscher-Ohlin framework) in the capital intensity of production, and there is, in addition, a sector that generates unproductive "appropriation" or conflict, with its participants essentially preying on the output of the productive sectors. Individuals freely sort themselves into the sectors; the equilibrium size of the "appropriation sector" is used as a measure of overall conflict.

Consider such an equilibrium and suppose that the capital-intensive sector receives a positive shock. Then wealth increases all around, but because the sector that benefits is relatively capital-intensive, the relative prices move against labor. The resulting lowering of wages (relative to other prices) permits the opportunity cost argument to come into its own: More labor flows into the appropriation sector, and conflict rises. (It can even be shown by example that the increase in conflict might overpower the positive shock that generated it in the first place, resulting in a negative outcome in the net.) Conversely, positive shocks to the labor-intensive sector (or policies that subsidize employment) will raise relative wages, implying this time that conflict declines. As for the net effect when the economy grows overall: Who knows? It would depend on whether that growth is balanced or not and, if not, on the technological profile of the sectors that benefit from growth.

The findings of Miguel et al. (2004) fit well within this framework. A weather shock impinges on agriculture, which is labor intensive. Thus, conflict is expected to rise with adverse shocks. This argument, while in no way negating the finding itself, calls into question the conceptual validity of the instrument as one that affects "overall growth." With a disaggregated view in mind, weather shocks can be seen as affecting particular segments of that economy - the labor-intensive agricultural sector, to be precise. Whether there is an overall negative causal relationship running from per capita income to conflict is not, therefore, established by this particular choice of instrument.

Dube \& Vargas (2013) explicitly cast their empirical study within the Dal Bo-Dal B ' o model. ' They study how internal conflicts in Colombia are affected by the movements of world prices for two commodities that are particularly pertinent to that country: oil and coffee. For each of these commodities, they interact its international price with the amount of that good produced in each municipality. When coffee prices rise, conflict falls more in coffee-producing municipalities. In sharp contrast, when oil prices rise, conflict increases in oil-producing municipalities. These observations are in line with the Dal Bo-Dal B ' o model. Coffee production is a relatively labor-intensive activity, so that a rise in coffee prices is likely to lead to an increase in wages relative to the overall price index. The opportunity cost argument then kicks in, reducing conflict. In contrast, oil extraction and processing are capital intensive, so that the opportunity cost argument runs in the opposite direction, with positive shocks generating conflict.

\section{ANALYSIS OF THE CRISIS IN ETHIOPIA-TIGRAY REGION}

This section of the article discusses the following concepts associated with Tigray ongoing crisis in Ethiopia: (a) uncovered abuses in the region; (b) the ongoing humanitarian aid to the region; (c) Troops attacks on food crops, factories and infrastructure in the region; (d) threat on communication; and (e) refugee camps.

\section{Uncovered Abuses in Tigray Region}

It was observed from the literature that before the heat of the crisis, people in Tigray suffered indiscriminate bombing by Ethiopian government forces, killing scores and forcing thousands to flee to Sudan or elsewhere in Ethiopia. Over the following months, Ethiopia, Eritrea, and Amhara troops burned crops, occupied and looted homes, and committed extrajudicial killings (Human Rights Watch, 2021). It was further observed from the literature that the region has undergone through 10 days of horror in the historic town of Axum, where Ethiopian and Eritrean forces shelled the town, then conducted widespread pillaging of the town and health centers. Eritrean forces there responded to an ambush by massacring scores of residents in their homes and on the street, including children (Human Rights Watch, 2021). Surprisingly, it has been documented in the literature that several executions, sexual violence, pillaging, arbitrary detention, and attacks on factories, schools, and hospitals are happening in the region.

\section{Challenges Associated with the ongoing humanitarian aid to the region}

According to Human Rights Watch (2021), after nearly a month where flights into Tigray were halted, the Ethiopian government permitted humanitarian flights into the region on July 22, although the United Nations said their staff faced stringent, time-consuming checks. It is observed from the literature that in the early part of June 
2020, there were almost 350,000 people facing starvation in Tigray. It was further observed from the literature that about 4 million people, that is, representing about 70 percent of the population, needed food aid (Human Rights Watch, 2021).

According to the literature, after the government's unilateral ceasefire declaration, humanitarian workers said that roads, notably through the neighboring Amhara region, were blocked off. Surprisingly, on July 2020 a bridge you have to cross to enter central Tigray was destroyed and a convoy of 29 trucks carrying food aid was forced to turn back (Human Rights Watch, 2021). Humanitarian workers have been largely unable to bring in food and medical supplies. The UN World Food Program (WFP) warned earlier this week that their supplies in Tigray are within days of running out (Human Rights Watch, 2021).

To make matters worse, humanitarian workers have been threatened and attacked. Since the conflict began, supposedly 12 aid workers have been killed in late June. Ethiopian defense forces entered and raided UNICEF offices in late June, dismantling critical communication equipment. Fighting parties, notably Eritrean government forces, have deliberately attacked and occupied medical facilities. In perusing the literature, it was further observed that social media influencers made the matter worse for the aid workers, whereby they repeatedly made false online claims against aid workers, thereby putting them at greater risk (Human Rights Watch, 2021).

\section{Troops Attacks on Food Crops, Factories and Infrastructure in the Tigray Region}

According to the recent happenings and the available reports, it was observed that Ethiopian troops and their allies from Eritrea and the Amhara region have looted and burned crops, and attacked factories and infrastructure (Human Rights Watch, 2021). Because the war started during harvesting season, the resultant negative impact of the war lead to the destruction of many food crops, factories, and infrastructure. In an interviewed conversation reported by Human Rights Watch (2021), it was observed that Tigrayans who fled to Sudan who reported that farming equipment and crops were burned and their harvest and livestock looted, notably by Amhara and Eritrean forces. For months, people were also just too scared to move, given the risks they faced.

\section{Ethiopian Federal Government's Restriction on Communication During Tigray Region Crisis and Its Impact on the People's Living Standards}

In relation to the war or the ongoing crisis, it has been observed from media reports that the phone lines are once again down in the region. The internet has been cut off since the beginning of the conflict. No phone service makes it difficult for people to receive key information, like which areas may be safe, or where to go if they need medical help (Human Rights Watch, 2021). It was also observed from the literature that the residents can't get information about family and friends. The restriction on communication and the disconnection of the telephone lines in the region due to the ongoing crisis also makes it incredibly difficult for humanitarian workers to help people, and to make decisions around security or to assess a community's needs. And it hinders the ability of journalists and human rights groups to collect information and report on unfolding abuses (Human Rights Watch, 2021).

\section{Refugee Camps in Tigray Region}

Surprisingly, it was observed from the literature that the two remaining camps for Eritrean refugees in Tigray were caught in the fighting between Tigrayan and Ethiopian government forces. The warring parties need to protect these vulnerable people, and the international community should be thinking about how to support and protect them as well. In fact, it noticed in many media report that earlier in the conflict, two other refugee camps hosting roughly 20,000 Eritrean refugees were destroyed by Eritrean forces, the military from the country where they fled repression and persecution (Human Rights Watch, 2021). Sadly, the Tigrayan militias also killed and sexually assaulted refugees in late 2020, in what appears to be unlawful revenge attacks because of abuses Eritrea's forces committed in Tigray at the time, including massacres, widespread pillaging, and sexual violence (Human Rights Watch, 2021)

\section{CONCLUSION AND POLICY IMPLICATIONS}

This section summaries and also discusses the various responses by UN (OHCHR), UK, \& USA to help restore peace to the Tigray crisis in Ethiopia. The response by the United Nations and influential governments has been slow and mixed. Over the last few months, there's been more concerted efforts by the United States, the European Union, and the United Kingdom about ensuring access to aid and calling for investigations into serious abuses. The African Commission on Human and Peoples' Rights has established a commission of inquiry, which the African Union needs to support with financial, technical, and political assistance. As part of the immediate responses to the crisis, the UN's Office of the High Commissioner For Human Rights (OHCHR) is conducting a joint investigation with Ethiopia's national human rights commission.

Despite the pressing need for intervention to rescue the Tigray crisis, the UN Human Rights Council was very slow to react to the crisis. In the interim, it was observed from media report that they only put Tigray on its agenda in mid-July. At the same time, the UN Security Council was in paralysis, discussing Ethiopia for months behind 
closed doors, with some member states saying the conflict was an "internal matter." As rightfully observed from the literature, it is critical that the key international bodies and governments move beyond condemnatory statements and adopt concrete action. They should push for credible, UN-led investigations, which could pave the way for the prosecution of those responsible for serious abuses. They should also impose individual sanctions on those responsible for violating international human rights and humanitarian law, and adopt an arms embargo.

In a press statement made by Anthony J. Blinken, Secretary of State on May 23, 2021 also signifies the critical need for the authorities to restore peace in Ethiopia. The Secretary of State, stated that "the United States has deepening concerns about the ongoing crisis in Ethiopia's Tigray region as well as other threats to the sovereignty, national unity, and territorial integrity of Ethiopia. People in Tigray continue to suffer human rights violations, abuses, and atrocities, and urgently needed humanitarian relief is being blocked by the Ethiopian and Eritrean militaries as well as other armed actors. Notwithstanding the significant diplomatic engagement, the parties to the conflict in Tigray have taken no meaningful steps to end hostilities or pursue a peaceful resolution of the political crisis. The United States condemns in the strongest terms the killings, forced removals, systemic sexual violence, and other human rights violations and abuses. We are equally appalled by the destruction of civilian property including water sources, hospitals, and medical facilities, taking place in Tigray. We call on the Ethiopian government to meet public commitments to hold accountable all those responsible for human rights violations and abuses, to protect civilians, and to ensure unhindered humanitarian access. We call for the Eritrean government to live up to its public commitment and immediately return its troops to internationally recognized Eritrean territory. Without an immediate cessation of hostilities and a rapid expansion of humanitarian access, current and significant food insecurity could lead to famine".

According to the House of Commons Library of the UK Parliament (2020), on November 4, 2020, the UK Government called for an immediate de-escalation in Tigray and a halt to violence. Foreign Secretary Dominic Raab also emphasized the need to protect civilians and allow humanitarian access in a phone call with Prime Minster Abiy on November 10, 2020. Additionally, James Duddridge, the Minister for Africa, also visisted Ethiopia in late July 2020. At the time Ethiopia was recovering from days of unrest following the killing of popular singer, Hachalu Hundessa. Following the urgent need for peace, the Minister called for more peaceful dialogue between the ethnic groups and for space to be given for political debate as a strategy to restore peace (House of Commons Library of the UK Parliament, 2020).

The European Union reported that it is getting consistent reports of ethnic-targeted killings and possible war crimes in Ethiopia's northern region of Tigray. The defense forces entered Tigray early in November to oust the region's ruling party after its troops had captured federal military bases (BBC News, 15 January, 2021). In BBC News report dated on 15 January, 2021, it was observed that in the report that the government of Ethiopia remains committed to working closely with its humanitarian and development partners to address any outstanding challenges that could hinder the safe, effective, and efficient delivery of humanitarian assistance to all affected populations. As result, Mr. Borrell said that the EU would continue to withhold $88 \mathrm{~m}$ euros $(\$ 106 \mathrm{~m} ; £ 78 \mathrm{~m})$ in budget support for Ethiopia until humanitarian access to Tigray region was allowed. He suggested that Sudan could help in finding a solution, given how Ethiopia had helped negotiate a peace deal after the overthrow of President Omar al-Bashir in 2019. He further promised that they will continue to support 'African solutions to African problems', in especially the pressing need of peace for Ethiopians.

Towards this end, the above information informs the general public and nations across the globe the need to restore peace in Ethiopia, therefore this current study recommends that policymakers, international peaceadvocates, Africa Union should act fast to assist Ethiopia, particularly Tigray region to end the ongoing crisis in order to restore peace and bring back development to Ethiopia and the surrounding countries.

\section{REFERENCES}

Ayene, M. (2021). Crisis in Ethiopia: New Conflict threatens the region. Crisis in Ethiopia: New conflict threatens the region International Rescue Committee (IRC)

Bethany, L., \& Gleditsch, N. P. (2005). Monitoring trends in global combat: a new dataset of battle deaths. European Journal Population. 21:145-66

BBC News. (15 January, 2021). Ethiopia Tigray Crisis: EU Concern over war Crime Reports. BBC News. Ethiopia Tigray crisis: EU concern over war crime reports - BBC News

Collier P, \& Hoeffler A. (2004). Conflicts. In Global Crises, Global Solutions, ed. B Lomberg, pp. 129-55. Cambridge, UK: Cambridge Univ. Press

Dal Bo E., \& Dal B ' o P. (2011). Workers, warriors, and criminals: social conflict in general equilibrium. Journal European Economics Association. 9:646-77

Dube, O., \& Vargas, J.F. (2013). Commodity price shocks and civil conflict: evidence from Colombia. Rev. Econ. Stud. 80:1384-421.

Fearon, J.D. (2003). Ethnic and cultural diversity by country. Journal Economics Growth 8:195-222.

Fearon, J.D. (2006). Ethnic mobilization and ethnic violence. In The Oxford Handbook of Political Economy, ed. BR Weingast, DA Wittman, pp. 852-68. Oxford, UK: Oxford University Press. 
Fearon, J.D., \& Laitin, D.D. (2003). Ethnicity, insurgency, and civil war. Am. Polit. Sci. Rev. 97(1):75-90.

Gleditsch, N.P., Wallensteen, P., Eriksson, M., Sollenber, M., \& Strand, H. (2002). Armed conflict 1946-2001: a new dataset. Journal Peace Research. 39:615-37.

Ginty, R. M., \& Williams, A. (2009). Conflict and Development. Routledge. www.taylorfrancis.com/books/mono/10.4324/9780203880005/conflict-development-roger-mac-gintyandrew-williams.

House of Commons Library of the UK Parliament. (2020). Ethiopia: Warnings of "full-scale humanitarian crisis" in Tigray region. UK Parliament. Ethiopia: Warnings of "full-scale humanitarian crisis" in Tigray region (parliament.uk)

Human Rights Watch. (2021). The Latest on the Crisis in the Ethiopia's Tigray Region. The Latest on the Crisis in Ethiopia's Tigray Region | Human Rights Watch (hrw.org)

Miguel, E., Satyanath, S., \& Sergenti, E. (2004). Economic shocks and civil conflict: an instrumental variables approach. J. Polit. Econ. 112:725-53.

Ray, D. \& Esteban, J. (2017). Conflict and Development. The Annual Review of Economics. 9:263-93. EstebanRayAnnReviews.pdf (nyu.edu)

U.S. Department of State. (2021). Press Statement by Anthony J. Blinken: United States' Actions to Press for the Resolution of the Crisis in the Tigray region of Ethiopia. United States' Actions To Press for the Resolution of the Crisis in the Tigray Region of Ethiopia - United States Department of State

Wealth Health Organization. (2021). Crisis in Northern Ethiopia (who.int). WHO. 